\title{
Influence of Heavy Metal Ions in Fisheries
}

\author{
R Biswas* \\ Department of Physics, Tezpur University, India
}

Submission: March 14, 2019; Published: April 02, 2019

Corresponding author: R Biswas, Applied Optics and Photonics Lab, Department of Physics, Tezpur University, Tezpur-784028, Assam, India

\section{Abstract}

This concise document reports about influence of heavy metal ions in fisheries. Highlighting briefly about the impending implicit dangers, it points out suggestive measures that can be undertaken in order to tackle this growing concern.

\section{Opinion}

Industrialization is considered as status quo of developed countries. The developing nations are also on the same budge. Because of rampant growth of industries, the natural aquatic bodies are slowly receding. The recess in water bodies has added to the woes of fisheries which reside on these scant aquatic systems. It is even more dreadful when the concentration of heavy metal ions is taken into consideration. It has now become a global concern [1-4]. In general, there is no concrete definition of heavy metals. However, above a certain threshold level of density, some metals are clustered into this category. They basically comprise of those elements in the periodic table whose density is above $4 \mathrm{~g} / \mathrm{cm} 3$. The metal ions satisfying this criterion are arsenic, lead, cobalt, nickel, mercury etc [4-6]. As per several reports, the concentrations of these ions are alarmingly at a higher level. They cause serious affects in the flora and fauna of aquatic habitats.

To begin with, lead is mostly found in many wells, fisheries or other natural abode of fishes. Excess of lead in aqueous solutions leads to acute poisoning. There is direct consequence of it in the breeding pattern of fishes. Major concern is that the foods on which they rely become contaminated with lead. This indirectly results in retarded reproduction. In some cases, some species are on the verge of extinctions or becoming endangered. In similitude to lead, there arise identical impacts from other heavy metal ions. As some of them are non-biodegradable; hence they tend to bio-accumulate. For instance, mercury as well as arsenic needs special mention. This has drastic influences on the compositional elements of aquatic culture. Precisely, the whole process leads to an ecological imbalance as most of them are interrelated to each other. The heavy metal ion contaminated fishes finally enter the human food chain which causes further health hazards in the long run.
Even though, WHO (World Health Organization) and Environment Protection agency (EPA) have been continuously keeping a close eye and put a benchmark of permissible limit regarding concentration of heavy metal ions, it is not at all adequate. The root causes behind these must be systematically identified as well as prohibitive measures are to be taken. It is needless to mention that aquatic bodies suffering from this pollution is mainly based on anthropogenic inputs. Noteworthy point is that many industrial products are based directly or indirectly on the use of these heavy metal ions. So, the industrial wastages should be properly monitored and there should be strict guidelines for zero or minimal discharge. In such cases, there should be development of cost-effective measures to check. In the same direction, punitive measures ought to be there for violation of norms. Additionally, rapid and cost-effective quantitative assessment as well as their subsequent removal should be performed [511]. When the nodal agencies as well as govt. implements the schemes in a synergistic manner with considerable control over emission as well as discharge norms, accompanied by emphasis on recyclability of industrial wastages, the impact on fisheries due to heavy metal ions could be effectively diminished up to the best possible extent. This will also help in restoring ecological balance.

\section{References}

1. R Biswas (2018) Challenging Factors Influencing Biodiversity. Biodiversity Online J 1(1).

2. R Biswas (2018) Plastic Pollution: A Menace to Marine Biology. Ad Oceanogr \& Marine Biol 1(1).

3. RBiswas (2018) Editorial. Journal of Environmental Hazards 1(2).

4. R Biswas (2019) Heavy metal ion pollution in aqueous solution: an environmental hazard. Int Journal of Environmental Sciences and Natural Resources 6(4). 
5. B S Baruah, R Biswas (2018) Selective detection of arsenic (III) based on colorimetric approach in aqueous medium using functionalised gold nanoparticles unit. Material Research Express 5(1).

6. S Biswas, R Biswas (2018) Water and Sustainability Issues: A global perspective. International Journal of Oceanography \& Aquaculture 2(3).

7. B S Baruah, R Biswas (2018) Localized surface plasmon resonance-based $U$-shaped optical fiber probe for the detection of $\mathrm{Pb} 2+$ in aqueous medium. Sensors and Actuators B Chemical 89: 276.

8. B S Baruah, R Biswas (2018) An optical fiber based surface plasmon resonance technique for sensing of lead ions: A toxic water pollutant Optical Fiber Technology 46: 152-156.
9. B S Baruah, R Biswas, P Deb (2019) A green colorimetric approach towards detection of arsenic (III): a pervasive environmental pollutant, Optics and Laser Technology 111: 825-829.

10. B S Baruah, R Biswas (2019) Mangifera indica leaf extract mediated gold nanoparticles: a novel platform for sensing of As (III). IEEE Sensors Letter 3(3).

11. BS Boruah, NK Daimari, R Biswas (2019) Functionalized silver nanoparticles as an effective medium towards trace determination of arsenic (III) in aqueous solution. Result in Physics 12: 2061-2065.

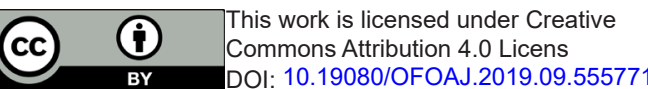

\section{Your next submission with Juniper Publishers} will reach you the below assets

- Quality Editorial service

- Swift Peer Review

- Reprints availability

- E-prints Service

- Manuscript Podcast for convenient understanding

- Global attainment for your research

- Manuscript accessibility in different formats

( Pdf, E-pub, Full Text, Audio)

- Unceasing customer service

Track the below URL for one-step submission https://juniperpublishers.com/online-submission.php 